\title{
Lobomycosis: epidemiology, clinical presentation, and management options
}

\author{
This article was published in the following Dove Press journal: \\ Therapeutics and Clinical Risk Management \\ 9 October 2014 \\ Number of times this article has been viewed
}

\author{
Valeska Albuquerque \\ Francesconi' \\ Ana Paula Klein² \\ Ana Paula Botelho Gualda \\ Santos ${ }^{2}$ \\ Rajendranath Ramasawmy ${ }^{3}$ \\ Fábio Francesconi ${ }^{4}$ \\ 'Department of Dermatology, Tropical \\ Medicine Foundation Heitor Vieira \\ Dourado, Manaus, Amazonas, Brazil; \\ ${ }^{2}$ Amazon Federal University, Manaus, \\ Amazonas, Brazil; ${ }^{3}$ Department of \\ Immunogenetics, ${ }^{4}$ Department of \\ Dermatology, Tropical Medicine \\ Foundation Heitor Vieira Dourado, \\ Manaus, Amazonas, Brazil
}

\begin{abstract}
Lobomycosis is a subcutaneous mycosis of chronic evolution caused by the Lacazia loboi fungus. Its distribution is almost exclusive in the Americas, and it has a particularly high prevalence in the Amazon basin. Cases of lobomycosis have been reported only in dolphins and humans. Its prevalence is higher among men who are active in the forest, such as rubber tappers, bushmen, miners, and Indian men. It is recognized that the traumatic implantation of the fungus on the skin is the route by which humans acquire this infection. The lesions affect mainly exposed areas such as the auricles and upper and lower limbs and are typically presented as keloid-like lesions. Currently, surgical removal is the therapeutic procedure of choice in initial cases. Despite the existing data and studies to date, the active immune mechanisms in this infection and its involvement in the control or development of lacaziosis have not been fully clarified. In recent years, little progress has been made in the appraisal of the epidemiologic aspects of the disease. So far, we have neither a population-based study nor any evaluation directed to the forest workers.
\end{abstract}

Keywords: infection, Lacazia loboi, lobomycosis, lacaziosis, mycosis

\section{Introduction}

Lobomycosis is a fungal infection caused by Lacazia loboi. This disease affects primarily the subcutaneous tissue manifested by a chronic granulomatous reaction, full of parasites, in the dermis. Keloid-like lesions are the most common clinical presentation. $^{1-3}$

With a clear geographic distribution, lobomycosis affects exposed populations of endemic areas in Latin America, with few reports of exported cases. ${ }^{4-6}$ A new epidemiologic scenario is linked with dolphins that are prone to acquiring lobomycosis. This new context expands the possibility of lobomycosis to every coastal region in which those cetaceans are found, raising the need for clinicians to recognize this emerging fungal infection.

\section{Etiology}

The first case report of lobomycosis was done in 1931 by the Brazilian dermatologist Jorge Lobo. This report was about a 52-year-old man who lived in the Amazon region and who presented with sacral lesions resembling keloid. This "new" disease was named "blastomicose keloidiana" (keloid blastomycosis). ${ }^{1}$

Since this first description, several names have been used to describe this entity: Jorge Lobo disease, Jorge Lobo mycosis, Jorge Lobo blastomycosis, amazonic pseudolepromatous blastomycosis, miraip or piraip (in the tupi language), Caiabi
Correspondence: Fábio Francesconi Department of Dermatology, Tropical Medicine Foundation Heitor Vieira Dourado, 25 Pedro Teixeira Ave, 69040000 Manaus, Amazonas, Brazil Tel +5592 21273555

Email fabiofranceconi@globo.com (c) (i) (5) 2014 Francesconi et al. This work is published by Dove Medical Press Limited, and licensed under Creative Commons Attribution - Non Commercial (unported, v3.0) $\mathrm{BY}$ NC License. The full terms of the License are available at http://creativecommons.org/licenses/by-n/3.0/. Non-commercial uses of the work are permitted without any further
permission from Dove Medical Press Limited, provided the work is properly attributed. Permissions beyond the scope of the License are administered by Dove Medical Press Limited. Information on permission from Dove Medical Press limited, provided the work is properly attributed. how to request permission may be found at: http://www.dovepress.com/permissions.php 
leprosy (Caiabi is an Indian tribe located in the state of Mato Grosso), and lacaziosis. Lobomycosis is the correct name for this disease. ${ }^{2}$

The taxonomy of this fungus is confusing and has changed several times since its first description. Glenosporella loboi was used by Fonseca Filho and Area Leao, ${ }^{3}$ Blastomyces brasiliensis by Conant and Howell, ${ }^{4}$ Glenosporosis amazonica by Fonseca Filho, ${ }^{5}$ Paracoccidioides loboi by Almeida and Lacaz, ${ }^{6}$ Blastomyces loboi by Langeron and Vanbreuseghem, ${ }^{7}$ and Lobomyces loboi by Borelli. ${ }^{8}$

The binomial Loboa loboi described by Ciferri et al is considered a "nomem nundum and illegitimate," and should not be used. ${ }^{9-11}$ Most recently, Taborda et al proposed the binomial Lacazia loboi, arguing that previous designations were taxonomically invalid. ${ }^{12}$

Herr et al, after amplifying the 18SSU ribosomal DNA (rDNA) and $600 \mathrm{bp}$ of the chitin synthetase gene, have contributed to the clarification of the taxonomic enigma of this agent, placing it in the group of the Onygenales order and Ajellomycetaceae family. ${ }^{13}$ Similarities between Paracoccidioides brasiliensis and L. loboi put both species in the same taxonomic complex. ${ }^{2,14}$ Electronic microscopy study showed similarities concerning cellular structure, although differences in reproduction could be demonstrated. ${ }^{15}$ Immunological similarities between these species have been described. ${ }^{2,11,16-19}$ Phylogenetic data strongly support the placement of L. loboi in its own species, separate from all known P. brasiliensis phylogenetic species. ${ }^{20}$

Regular round-shaped yeasts, isolated or in a chain, are the typical presentation of $L$. loboi in tissues. The size is approximately $6 \times 13.5 \times 11 \mu \mathrm{m}$, with a birefringent membrane and thick wall containing melanin. Reproduction with simple gemmulation, without exporulation, forms the blastoconidia and leads to the typical rosary bead figures. ${ }^{19,20}$

The impossibility of cultivating the species $L$. loboi in culture medium is believed to be an adaptation to the parasitic life of the fungus. ${ }^{20}$ Inoculations have been described in several animals, including hamster testis, ${ }^{21}$ hamster cheek pouch, ${ }^{22}$ armadillo (Euphractus sexcinctus), and turtles, but have produced no satisfactory response in mice. ${ }^{23}$ Culture in chorioallantoic membrane of embryonic chicken eggs and disease after accidental inoculation in humans has also been described. ${ }^{24,25}$

\section{Pathogenesis}

Lobomycosis can cause primary skin infection in humans and dolphins. Trauma is considered the pivotal event. It is believed that L. loboi, which is saprophytic in soil, vegetation, and water, must be inoculated within the dermis to start an infection. ${ }^{26}$ Some speculate transmission is related to insect or animal inoculation based in reports in which the symptoms occurred after snakebite, stingray accident, or insect bite. ${ }^{27}$

In the dermis, the fungus starts its proliferative phase within the macrophages. ${ }^{28}$ By direct influence of the microorganism, transforming growth factor $\beta 1$ concentration increases. Transforming growth factor $\beta 1$ is a cytokine produced by macrophages and Th3 lymphocytes and is considered to be a potent immunosuppressive molecule. This cytokine is expressed in histiocytes and multinucleated giant cells and diffuses in the inflammatory infiltrate of patients with lobomycosis. ${ }^{29}$ It suppresses the phagocytic activity of macrophages and has the capacity to inhibit nitric oxide and gamma interferon expression, consequently impairing the cell-mediated immunity. ${ }^{29-33}$ In addition, this cytokine can promote the proliferation of CD8 T lymphocytes, stimulating the production of immunoglobulin A antibodies by plasma cells and the process of fibrosis, including the formation of extracellular matrix, contributing with the keloid-like appearance of the clinical lesion. ${ }^{23,31,34}$

Another cytokine found in the dermis of lobomycosis patients is interleukin 10 (IL-10). Together with transforming growth factor $\beta 1$, IL-10 acts by inhibiting the cellular immune response and, as a consequence, the activation of macrophages. ${ }^{29}$ The negative effect on cellular immunity could create a localized environment of specific immunodeficiency, as demonstrated by the absence of a response to dinitrochlorobenzene, as well as delayed responses to Staphylococci, Streptococci, Trichophyton, and Candida antigens. ${ }^{28,35}$ Immunoglobulin and complemented characterization of the lesions are in agreement with the findings of a T helper 2 profile. $^{36}$

Quaresma, in 2010, created the hypothesis that Langerhans cells could modulate local infection, helping the fungus to evade the immune system. ${ }^{37}$ The leukocyte and neutrophil functions, as well as complement activity, are preserved in patients with Jorge Lobo's disease. ${ }^{38,39}$ Studies of humoral immunity in patients with lobomycosis exhibit a Th2 cytokine profile with increased production of IL-4 and IL-6 and lower production of IL2. ${ }^{28,35,40}$ Some authors believe in a protective factor caused by the presence of the melanin within the fungus wall. ${ }^{41}$

In spite of all defensive mechanisms, fungal viability indices range from $20 \%-50 \%{ }^{42}$ The mechanisms that lead to in situ $L$. loboi cell lysis are still unknown. It is possible that CD8 T lymphocytes or natural killer cells exert a cytotoxic effect by lysing macrophages infected with the 
fungus through a mechanism dependent on exocytosis of granules containing perforin and granzyme, similar to what occurs in other infectious diseases. ${ }^{43-45}$ Another possibility is the participation of the complement system, as deposits of the $\mathrm{C} 3 \mathrm{c}$ component on the fungal cell wall in histological sections obtained from patients with the mycosis could be demonstrated. ${ }^{36}$

Molecular techniques identified eight antigens of P. brasiliensis $(29-108 \mathrm{kDa})$ in sera of infected hosts with L. loboi. ${ }^{46}$ Mendoza et al, in 2008, used specific L. loboi antigens extracted from mice as well as from dolphins with Jorge Lobo's disease. They demonstrated that an immunodominant antigen with a high molecular weight of $\sim 193 \mathrm{kDa}$ was recognized by antibodies in the serum, suggesting that the antigenic proteins of $L$. loboi have much higher molecular weight than the counterpart, gp43, of P. brasiliensis. ${ }^{47}$

Preserved cellular immunity is probably necessary to hinder the progression of the disease, or in some cases, prevent its appearance. Nowadays it is not possible to identify sub-clinical lobomycosis due to lack of a specific and reliable antigen. Lobina, once used for this purpose, lacks specificity and may present cross reaction with other agents such as $P$. brasiliensis and some mycetoma agents. Because there is no way to correctly identify cases of lobomycosis infection, at this time it is not possible to know the exact number of infected people or the percentage of them that present with the disease. ${ }^{48}$

After the proliferative phase in the dermis, there is a possibility of a dissemination phase through lymphatics. Reports of regional lymph node enlargement and lymphatic spread of the disease have both been described, and supports this hypothesis. It is not known, however, how many patients evolve with lymphatic disease. ${ }^{49}$

Contiguous dissemination and/or autoinoculation have also been described. Repetitive traumatism cannot be discarded in many cases because the patient is still under the epidemiologic risk of being infected. There is only one reported case of systemic lesion caused by possible $L$. loboi where the testicle was involved, probably after hematogenous spread. Human transmission has never occurred, although experimental autoinoculation and accidental inoculation both have been reported. ${ }^{24,25,50}$

\section{Epidemiology and geographic distribution}

The biogeographic complex of $L$. loboi is situated in areas of forests with dense vegetation and large rivers. The annual rainfall is usually more than $2,000 \mathrm{~mm} /$ year, with an average temperature of $24^{\circ} \mathrm{C}$ and relative humidity of $75 \%$.
Those climatic characteristics are found in the tropical region of the Amazon basin, where most of the cases have been described. ${ }^{51}$

Since its first description, "keloid blastomycosis" was believed to be specific to areas of forests with high heat and humidity. Until that time, it mainly affected male forest workers. ${ }^{52}$ Jorge Lobo's disease was relatively frequent in the Amazon region, ${ }^{53}$ with most cases originating from the Brazilian Amazon region. ${ }^{54}$ By 1950, the first case of lobomycosis was described in Central America, and reports of the disease in Central and South America have been published regularly ever since. By 2000, only 3 of 465 human cases had been published outside the Amazon basin. ${ }^{23}$

The ecological niche of the fungus is expanding. The identification of the disease in dolphins was first made in the bottlenose dolphin (Tursiops truncatus) from the Atlantic coast of the United States at the Gulf of Mexico; ${ }^{55}$ it is also endemic in Florida coastal estuaries. The disease also affects the Guyana dolphin (Sotalia guianensis) from the Suriname River. ${ }^{55-60}$ Reports of photographic evidence of lobomycosis-like disease in dolphins from the Indian Ocean, the Japanese coast, the Brazilian South coast, the western Pacific, the Africa coast, the European coast, and the North Carolina coast show the regions where lobomycosis can be found. . $7,59,61-63^{-63}$

The dolphins of the endemic areas, botos (Inia geoffrensis) and tucuxis (Sotalia fluviatilis), that inhabit the Amazon and Orinoco river basins of Brazil and Venezuela, respectively, where the human disease is endemic, do not present with lobomycosis. ${ }^{58}$

To date, occurences of Jorge Lobo's disease in humans were reported in nine countries of South America (Brazil, Colombia, ${ }^{26,64,65}$ Suriname, ${ }^{66}$ Venezuela, ${ }^{58,67-71}$ Guyana, French Guiana, ${ }^{72-74}$ Ecuador, ${ }^{75}$ Peru,,${ }^{76-78}$ and Bolivia $\left.{ }^{79}\right)$, three countries of Central America (Panama, ${ }^{80,81}$ Costa Rica, ${ }^{82}$ and Mexico), and imported cases in the United States, ${ }^{83}$ Canada, ${ }^{84}$ France, ${ }^{85}$ Netherlands,${ }^{86}$ Germany, ${ }^{87}$ Greece,${ }^{88}$ and South Africa. ${ }^{69}$

For some time, it was believed that genetic predisposition was crucial for acquiring the disease once it affected preferably indigenous populations. ${ }^{89,90}$ Baruzzi et al were the first to demonstrate the link between geography and lobomycosis. The authors showed that after transferring the Caiabi Indians from the Tapajos River region to the Indian Xingu National Park, there were no more new cases of lobomycosis detected. The same study ${ }^{89}$ incisively reinforces the importance of location in the occurrence of lobomycosis. ${ }^{89,91,92}$ 
Lobomycosis can now be included in different epidemiologic contexts: occupational or recreational infection in endemic areas, occupational hazard for professions dealing with dolphins, and emerging infection in many coastal regions. This disease is classically an opportunistic infection that affects vulnerable populations living and working in forest areas, especially extrativists forest workers, river dwellers, and the Indian population. Nowadays, there is an increasing interest in products and substances derived from the forest. The need to preserve the native vegetation during extraction leads to strategies of sustainable harvesting for a new market. Those workers must be protected from all the diseases related to the forest environment, including lobomycosis. ${ }^{65,89,91,93-97}$

Since the description of natural disease in dolphins and the report of a zoonotic transmission in an aquarium worker after contact with a sick dolphin, ${ }^{86}$ lobomycosis can be included in the list of zoonotic mycosis. ${ }^{61}$ It is an occupational hazard for veterinarians, marine biologists, and others who handle dolphins during health assessments, rescue operations, and rehabilitation efforts of stranded or injured animals. Direct and indirect human contact with dolphins have expanded because of the increased number of dolphins under managed care in aquarium and commercial exhibitions, as well as in swimming-with-dolphins programs for recreational or therapeutic benefit. ${ }^{86,87}$

Zoonotic transmission from dolphins is presumed, the clearest evidence of which was described in an aquarium attendant with a hand lesion that occurred after managing a sick animal. ${ }^{86}$ Other cases in which zoonotic transmission is suspected have been published. The first case was a patient from Suriname, ${ }^{98}$ an area where lobomycosis occurs in Guiana dolphins (S. guianensis) that inhabit the Suriname River estuary, ${ }^{99}$ and the second case developed in a young man from South Africa who was an avid swimmer and diver. ${ }^{100}$ The third occurred in a fisherman from Venezuela who developed lesions on the ear after being pierced with a fishing hook in a coastal area where an affected dolphin was observed. ${ }^{67}$ Most recently, lobomycosis was diagnosed in a female farmer with hypoglobulinemia and common variable immunodeficiency and hepatitis who lived on the Greek coast. ${ }^{88}$

A report by a dermatologist who suffered an accidental laceration during a biopsy procedure of a dolphin with lobomycosis ${ }^{101}$ without subsequent development of lobomycosis suggest that transmission from dolphins to humans, even through direct inoculation, is unlikely in immunocompetent individuals.
Morphologically, the organisms found in dolphin differ when compared with human L. loboi. They are smaller and have morphometric and ultrastructural differences in the cell wall. ${ }^{102}$ Molecular sequencing of rDNA from an infected dolphin showed a novel sequence related more closely to P. brasiliensis than to L. loboi of human origin. ${ }^{103}$

This recent evidence is supported by an earlier study that showed that ribosomal RNA gene sequences from an infected dolphin were $97 \%$ homologous with P. brasiliensis. ${ }^{57}$ In contrast, serum from an infected dolphin recognized an immunodominant 193-kDa antigen from an extract of human L. loboi more strongly than the gp 43 antigen of P. brasiliensis in western blotting analyses. ${ }^{47}$

Experimental inoculation of a laboratory scientist with yeast-like cells from a human patient, as well as a report of an accidental transmission of lobomycosis in another laboratory scientist who collected and purified fungal cells from human skin biopsies, ${ }^{50}$ imply that under unusual circumstances, Lacazia of human origin can be transmitted to other humans. ${ }^{24}$

The epidemiologic data of lobomycosis in endemic areas is unknown. The largest casuistic comes from Acre, Brazil. A retrospective study identified 249 patients diagnosed with lobomycosis in a period between 1998 and 2008; the calculated prevalence was $3.05 / 10,000$ inhabitants. This number is probably underestimated because the population at epidemiologic risk lives in the forest, with difficult access to the health system. ${ }^{104}$

\section{Clinical presentation}

After an unknown incubation period, estimated to be between 1-2 years, lobomycosis affects predominantly exposed areas (pinna in $38 \%$, upper limbs in $28 \%$, lower limbs in $22 \%$ ) of adult males who develop activities in the forest (Figure 1).,105 Localized disease represents $61 \%$ of the cases. ${ }^{104}$ The time between the first signs of the disease and the diagnosis varies from months to decades. In the Woods article, the average time was 19 years. ${ }^{83}$

The initial lesion is a papule: depending on the level of the trauma, it may be superficial or deep. Slow progression in a period of months to years leads to the formation of a plaque or nodule. The primary lesion is covered by smooth and shiny intact skin. The surface color varies from the patient's color to erythematous-brownish or red-wine, with or without telangiectasia. Those characteristics give the typical presentation a fibrous appearance, resembling a scar or a keloid (Figure 2). ${ }^{23}$

Chronic by nature, localized in trauma-prone areas, and exposed to a moist environment, the clinical lesions may suffer 


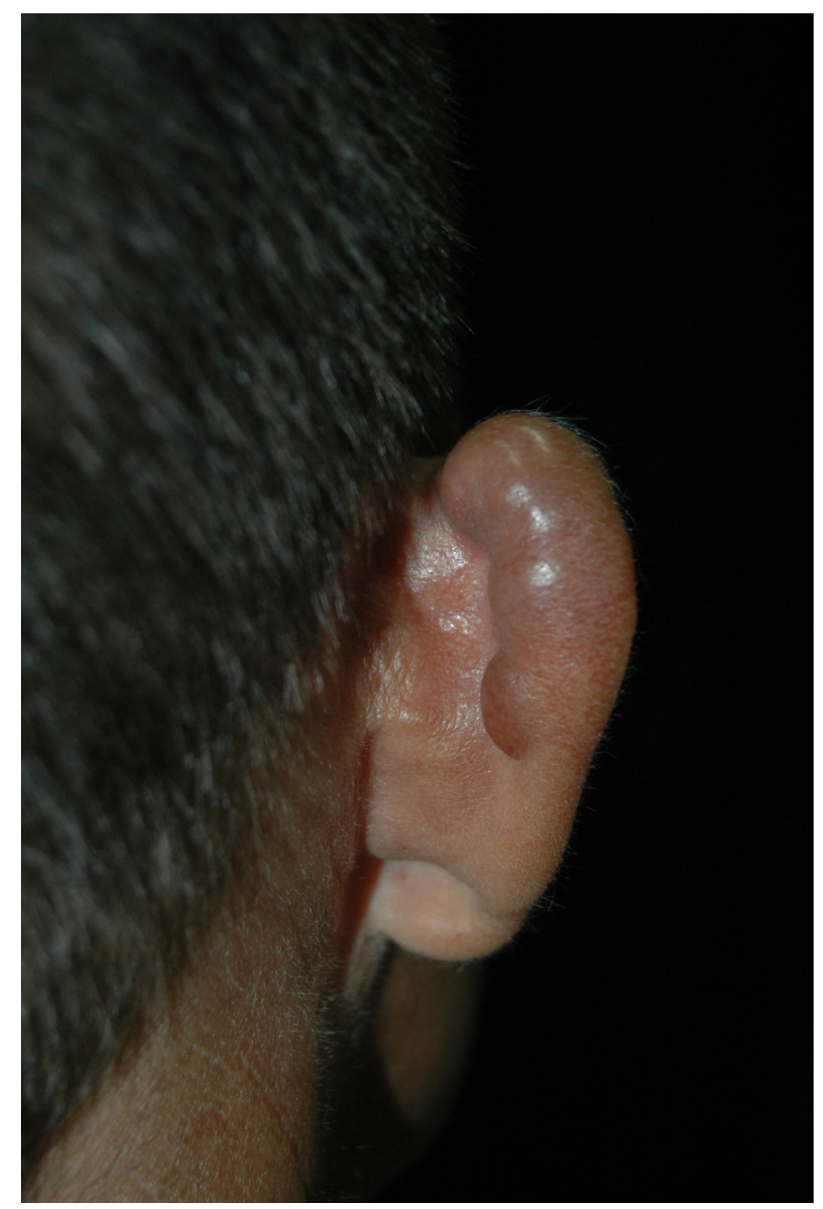

Figure I Patient presents with multiple nodules in the right auricle, a typically affected area.

modifications leading to a more polymorphic clinical picture. Dyschromic changes are commonly described, varying from hyperpigmentation to hypopigmentation and achromia. ${ }^{7,23}$

Ulcers are believed to be secondary to trauma, especially after maceration that occurs in the rainy season.

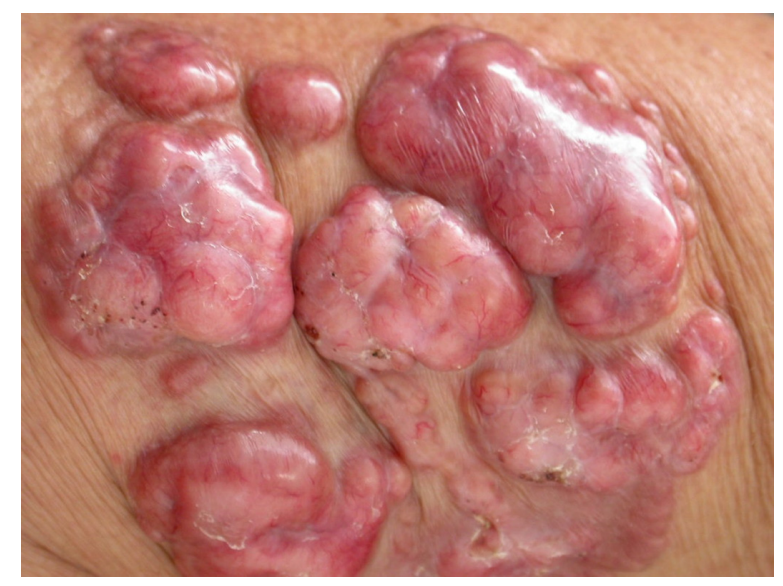

Figure 2 Typical primary fibrous appearance, with nodular plaques covered by smooth and shiny skin, with small exulcerated areas and visible telangiectasias.
Deeper lesions are probably related to recent inoculated lesions and are described as infiltrative. Continuous growth may bestow an exophytic appearance in some cases (Figure 3). ${ }^{13,23,93}$

Some of these lesions may present with a wart-like surface leading to verrucous lobomycosis. This clinical picture typically affects the lower limbs and imposes differential diagnosis with chromomycosis. ${ }^{23,106}$

Gummalike lobomycosis is rarely seen. It is described as occurring in macular lesions that evolve with turgid borders, followed by pustules and finally an exudation of a thick yellow material. Scar tissue eventually develops. This phenomenon can occur several times in the same lesion and is associated with spontaneous resolution, an extremely rare event. ${ }^{96}$ There is only one report of spontaneous resolution, accompanied by cicatricial areas without fungal elements after an episode of lobomycosis..$^{93}$

Emergence of new wounds around the index lesion raises questions about autoinoculation or local lymphatic dissemination, although continuous exposure cannot be discarded. This picture may lead to confluent lesions forming big plaques or the presence of hundreds of lesions. Autoinoculation has been documented in a case where the donor site for skin graft evolved with a lobomycosis lesion; contaminated material was the probable cause. ${ }^{106}$ Local

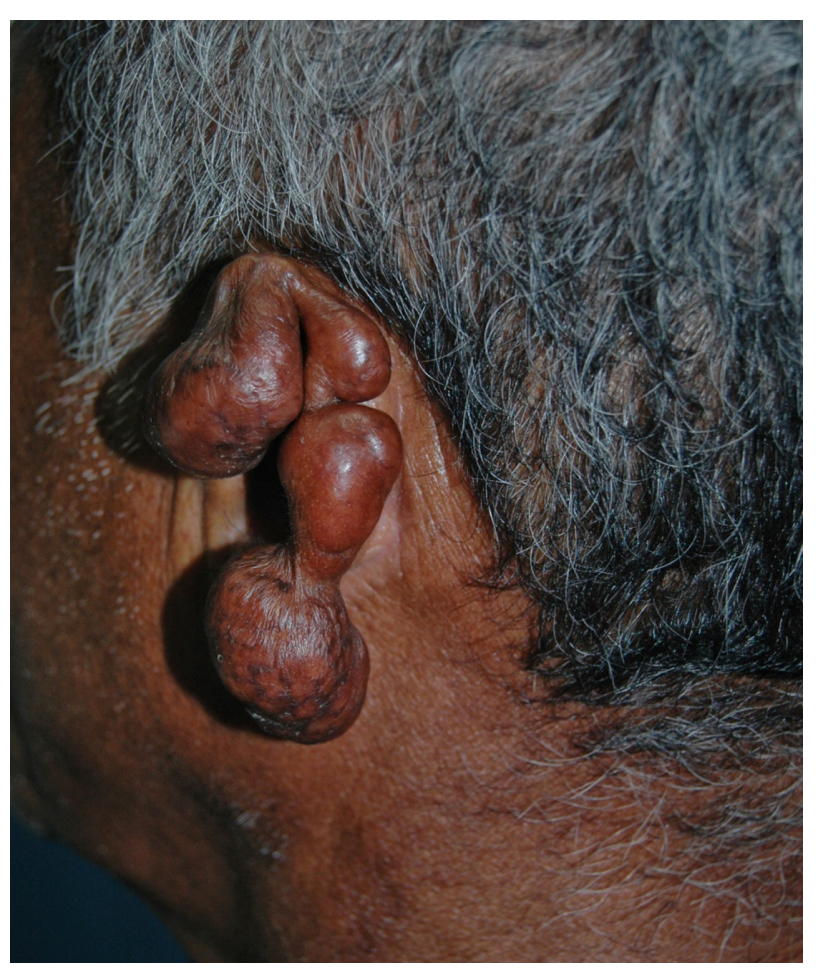

Figure 3 Local destruction of the left auricle, presenting exophytic erythematousbrownish lesion, with a pedunculated aspect and telangiectasias. 
lymphatic spread of the disease has been reported with estimated occurrence of $10 \%$ to $25 \% \cdot{ }^{49,107}$ In one case, the testicle was affected, and hematogenous spread of the fungus was implicated as the cause. ${ }^{26}$

Symptoms are rarely associated with lobomycosis lesions. Pruritus and dysesthesia are symptoms more often described in extensive cases. The progressive nature may lead to deformation, causing functional and aesthetic concerns. ${ }^{104}$ Carcinomatous degeneration is a possible and feared complication (Figure 4). ${ }^{104,108}$

Classifications have been proposed and are essentially based on clinical aspects of the disease. A morphologic classification subdivided the cases into infiltrative, keloid-like, in plaques, verruciform, and ulcerated forms (Figure 5). ${ }^{109,110}$ A classification based on the immunologic response to the fungus was proposed by Machado: hyperergic (macules and gumma) and hypoergic (keloid-like). ${ }^{111}$ An operational approach proposed one classification based on the distribution of the disease as follows: localized or isolated disease, multifocal disease (restricted to an anatomical area), or disseminated disease (more than one anatomical segment).

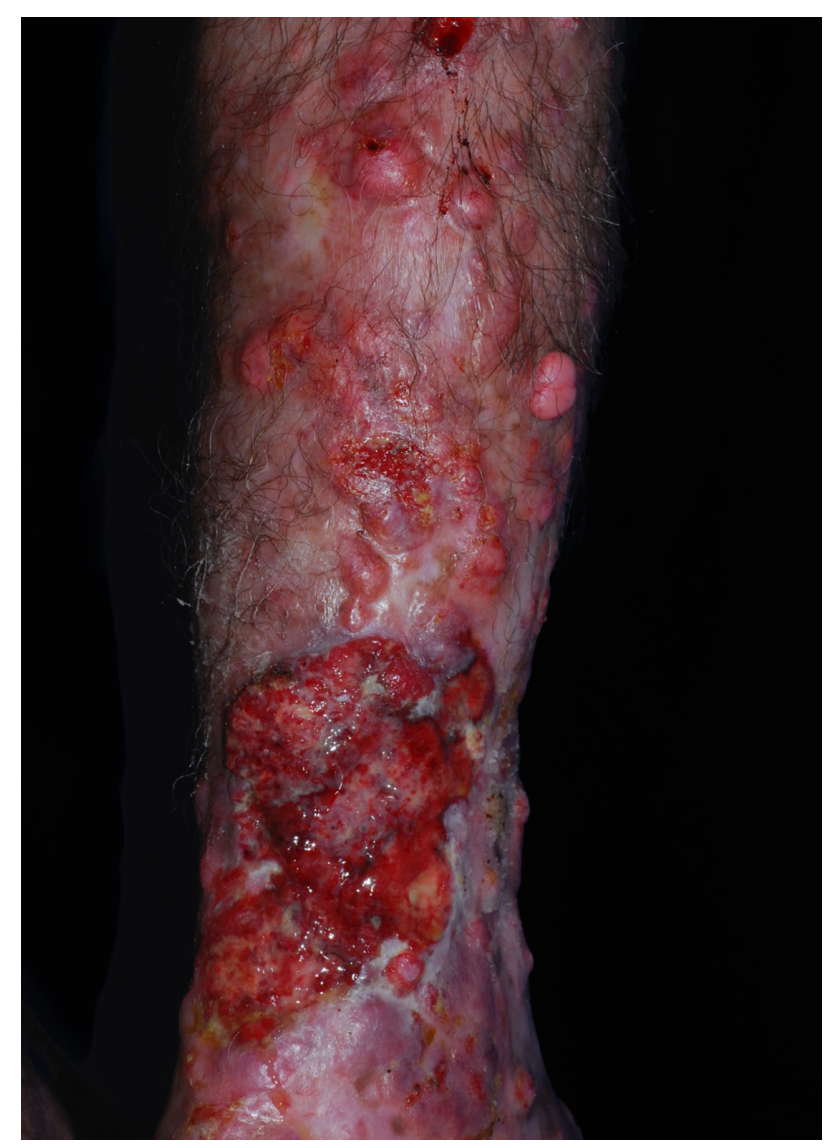

Figure 4 Superimposed carcinomatous degeneration on typical fibrous Lacaziosis nodules.

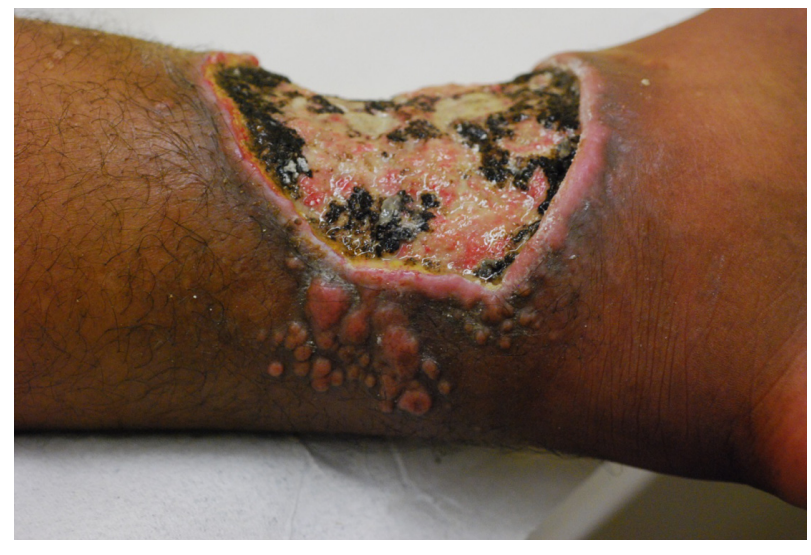

Figure 5 Ulcerated presentation with small fibrous plaques and nodules at its borders.

This classification is aimed to program the therapeutic strategy. ${ }^{104}$

\section{Diagnosis}

Diagnosis is primarily based on clinical aspects of the lesion. It should be confirmed by identifying the numerous agents within the lesion. Round and oval yeast-like structures with regular size, between 6-12 $\mu \mathrm{m}$, and a birefringent membrane are found in the dermis. The fungal structures may be found isolated or with a simple gemmulation; the typical catenular or Rosario beads distribution is commonly found (Figure 6). Direct examination by scraping the lesions is the simplest way to visualize the fungus. Alternatively, techniques such as vinyl adhesive tape or exfoliative cytology may also be used. ${ }^{112-114}$

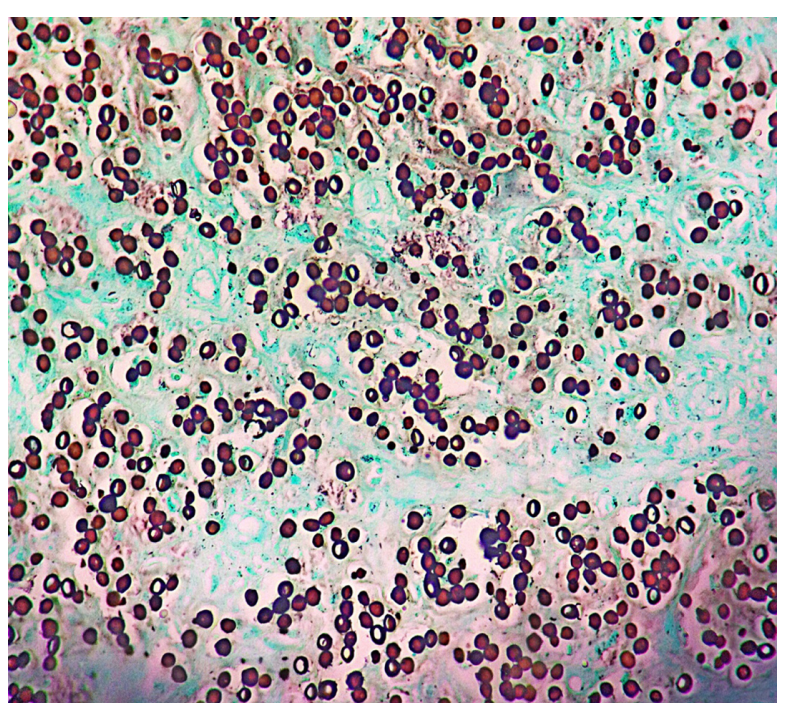

Figure 6 Histological section showing round and oval yeast-link structures with birefringent membrane, with isolated and Rosario beads distribution, commonly found in Jorge Lobo's disease.

Note: Grocott methenamine silver-stained, 400×. 
The histopathology of the lesions sent for biopsies are obtained by routine staining with hematoxylin-eosin, with the agents better visualized with silver stains. The characteristic histopathologic picture is composed by a dense and diffuse histiocytic infiltrate of the dermis, with an overwhelming number of parasites. Occasionally, the Unna band may be observed. ${ }^{26}$

The epidermis is typically presented with rectification of the rete ridges or atrophic areas above a thin Grenz band. ${ }^{115}$ Acanthotic areas with the presence of hyperkeratosis, spongiosis, and neutrophil collection may be observed. ${ }^{113}$ Those changes are probably elicited by the presence of the fungus in the epidermis. ${ }^{116}$ Hyperplastic infundibulum is associated with transepidermal elimination of the fungus. ${ }^{113}$ This phenomenon has already been documented and is the basis for the vinyl adhesive tape technic. ${ }^{112}$

The dense histiocytic dermal infiltrate is composed of a large number of epithelioid, multinucleated, and Langhans cells with or without the presence of granulomas (Figure 7). Sometimes, aggregates of large xanthomatous histiocytes with clear cytoplasm or finely granular eosinophilic cytoplasm, without parasites within, can be found. Those are called pseudo-Gaucher cells. ${ }^{113} \mathrm{~A}$ great number of fungal structures are found within the macrophages or in the dermis. Lymphocytes are present in discrete to moderate numbers, with a predominance of CD4 $\mathrm{T}$ lymphocytes and a CD4:CD8 ratio of approximately $3: 2$. Plasma cells and B lymphocytes are less frequent than $\mathrm{T}$ lymphocytes, with natural killer cells always present. ${ }^{29,117}$ Neutrophils are rarely found and are associated with ulcers or fungus within the epidermis. Fibrosis is a striking feature, and Asteroid bodies may be seen. ${ }^{23}$

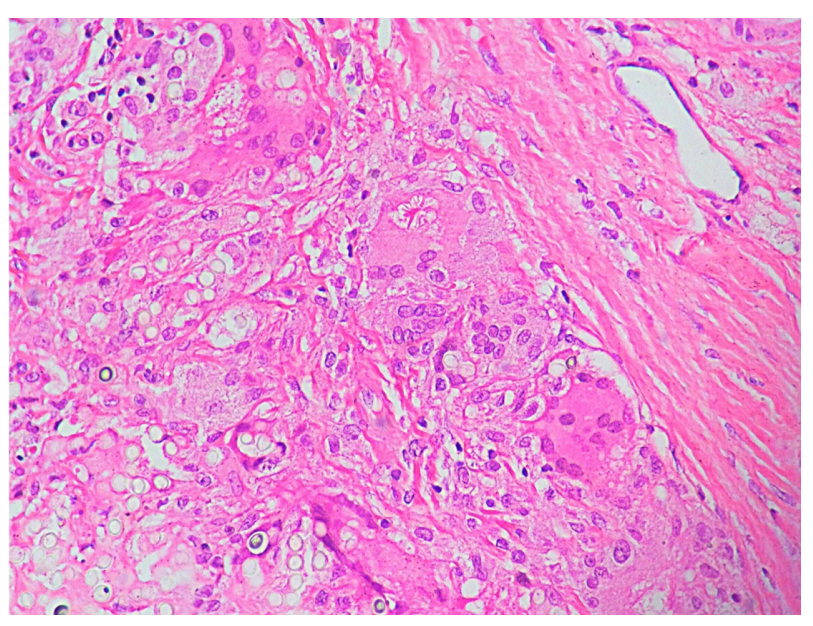

Figure 7 Histological section of a patient with lobomycosis. Notes: Notice the inflammatory infiltrate with multinucleate giant cells, dispersed fungi, a large number of histiocytes, and a single asteroid body. Hematoxylin-eosin, 400x.

\section{Treatment}

The ideal treatment is wide surgical excision. It is worth noting that instruments contaminated during operation can lead to reinfection. ${ }^{106}$

There is no optimal drug treatment for cases in which surgery is contraindicated or for disseminated infection. The only successful oral treatment with complete response was reported in a dolphin, using myconazol. ${ }^{118}$ Many antifungal agents have been tested with unsatisfying results: ketoconazole, ${ }^{79,119,120}$ amphotericin $\mathrm{B},{ }^{121}$ sulfa compounds, ${ }^{122}$ and 5-fluorocystosine ${ }^{123}$ all have been proved inefficient. Itraconazole has been shown to be partially effective and can be used as an adjuvant to prevent recurrence of surgically removed lesions. ${ }^{124}$ Itraconazole with cryosurgery has been successfully used to treat relapse of lobomycosis. ${ }^{123,124}$ Clofazimine, with dosages of 100-300 mg daily for up to 2 years, has been used in some reports, with unsatisfactory results. ${ }^{125-127}$ Interestingly, as per the experience of the Leprosy Elimination Programme of Acre, in Brazil, patients with lobomycosis and concurrent leprosy have been shown to respond to multibacillary therapy with reduction of pruritus and size of the mycotic nodules. ${ }^{104}$

The new azoles with expanded spectrum may prove to be efficacious. Posaconazole has been used for 24 months and has achieved the cure of the lesion without remission in 5 -year follow-up. ${ }^{78}$

Because of the recurrence of lesions, in cases of surgical removal, patient follow-up is necessary for a long time before considering it cured. To date, there is no efficient drug treatment, and surgical removal is the most-used therapeutic procedure.

\section{Disclosure}

The authors report no conflicts of interest in this work.

\section{References}

1. Lobo JO. Um caso de blastomicose produzido por uma espécie nova, encontrada em Recife. Rev Med Pernambuco. 1931;1:763-765.

2. Lacaz CD, Porto E, Martins JEC, Heins-Vaccari EM, de Melo NT. Doença de Jorge Lobo. Tratado de Micologia Médica Lacaz. 9th ed. São Paulo: Sarvier; 2002:462-478. Brazilian.

3. Fonseca Filho O, Area Leão AE. Contribuição para o conhecimento das granulomatoses blastomycoides: o agente etiológico da doença de Jorge Lobo. Rev Med Cirurg Brasil. 1940;48:147-158.

4. Fonseca Filho O, Arêa Leão AE. Contribuição para o conhecimento das granulomatoses blastomicoides. O agente etiológico da doença de Jorge Lobo. Bol Acad Nac Med Rio de J. 1940;112:42-53. Brazilian.

5. Fonseca Filho O. Glenosporella loboi. In: Fonseca Filho O, editor. Parasitologia Médica Parasitos e Doenças Parasitárias do Homem. Rio de Janeiro: Guanabara Koogan; 1943:703-725. Brazilian.

6. Almeida FP, Lacaz CS. Blastomicose "tipo Jorge Lobo." An Fac Med S Paulo. 1948-1949;24:5-37. 
7. Langeron M, Vanbreuseghem R. La blastomycose chéloidienne ou maladie die Jorge Lobo. In: Langeron M, Vanbreuseghem R, editors. Précis de Mycologie. Deuxième. Paris: Masson; 1952:490-491. French.

8. Borelli D. Lobomicosis: nomenclatura de agente (revisión critica). Med Cutanea. 1968;3(2):151-156.

9. Fonseca OJM, Lacaz CdaS. Estudo de culturas isoladas de blastomicose queloidiforme (doença de Jorge Lobo). Denominação ao seu agente etiològico. Rev Inst Med Trop São Paulo. 1971;13:225-251.

10. Azevedo DE, Campos S, Carneiro LS, Ciferri R. Advance in the knowledge of the fungus of Jorge Lobo's disease. J Trop Med Hyg. 1956;59(9):214-215.

11. Silva ME, Kaplan W, Miranda JL. Antigenic relationships between Paracoccidioides loboi and other pathogenic fungi determined by immunofluorescence. Mycopathol Mycol Appl. 1968;36(2):97-106.

12. Taborda PR, Taborda VA, McGinnis MR. Lacazia loboi gen. nov, comb. nov, the etiologic agent of lobomycosis. J Clin Microbiol. 1999;37(6):2031-2033.

13. Herr RA, Tarcha EJ, Taborda PR, Taylor JW, Ajello L, Mendoza L. Phylogenetic analysis of Lacazia loboi places this previously uncharacterized pathogen within the dimorphic Onygenales. J Clin Microbiol. 2001;39(1):309-314.

14. Lacaz Cda C. Paracoccidioides loboi (Fonseca Filho et Arêa Leão, 1940) Almeida et Lacaz, 1948-1949. Description of the fungus in Latin. Rev Inst Med Trop Sao Paulo. 1996;38(3):229-231.

15. Furtado JS, De Brito T, Freymuller E. Structure and reproduction of Paracoccidioides loboi. Mycologia. 1967;59:286-294.

16. Mendes E, Michalany N, Mendes NF. Comparison of the cell walls of Paracoccidioides loboi and Paracoccidioides brasiliensis by using polysaccharide-binding dyes. Int J Tissue React. 1986(3):229-231.

17. Landman G, Velludo MA, Lopes JA, Mendes E. Crossedantigenicity between the etiologic agents of lobomycosis and paraccocidioidomycosis evidenced by an immunoenzymatic method (PAP). Allergol Immunopathol (Madr). 1988;16(4):215-218.

18. Puccia R, Travassos LR. 43-kilodalton glycoprotein from Paracoccidioides brasiliensis: immunochemical reactions with sera from patients with paracoccidioidomycosis, histoplasmosis, or Jorge Lobo's disease. J Clin Microbiol. 1991;29(8):1610-1615.

19. Vidal MS, Palacios SA, de Melo NT, Lacaz Cda S. Reactivity of anti-gp43 antibodies from Paracoccidioides brasiliensis antiserum with extracts from cutaneous lesions of Lobo's disease. Preliminary note. Rev Inst Med Trop Sao Paulo. 1997;39(1):35-37.

20. Vilela R, Rosa PS, Belone AF, Taylor JW, Diório SM, Mendoza L. Molecular phylogeny of animal pathogen Lacazia loboi inferred from rDNA and DNA coding sequences. Mycol Res. 2009;113(Pt 8):851-857.

21. Nery-Guamaraes F. Inoculacoes em hamsters da blasto micose sul-americana (doenca de Lutz), da blastomicose queloideana (doenca de Lobo) e da blastomicose dos indios do Tapajos-Xingu [Inoculations in hamsters of South American blastomycosis (Lutz's disease), keloid-like blastomycosis (Lobo's disease) and blastomycosis from the Indians of Tapaj'os-Cingu]. Hospital (Rio J). 1964;66:581-593. Portuguese.

22. Sampaio MM, Dias LB. Experimental infection of Jorge Lôbo's disease in the cheek-pouch of the golden hamster. Rev Inst Med Trop Sao Paulo. 1970;12(2):115-120.

23. Cardoso de Brito A, Quaresma JAS. Lacaziosis (Jorge Lobo's disease): review and update. An Bras Dermatol. 2007;82:461-474.

24. Borelli D. Lobomicosis experimental. Derm Venez. 1962;3:72-82.

25. Leite MC. Doença de Jorge Lobo (estudo de uma autoinoculação). Monografia. Belém: UFPA; 1993;34.

26. Rodríguez-Toro G. Lobomycosis. Int J Dermatol. 1993;32(5): 324-332.

27. Campo-Aasen I. Blastomicosis queloidiana o enfermedad de Jorge Lobo en Venezuela. Derm Venez. 1958;1:215-240.

28. Pecher SA, Croce J, Ferri RG. Study of humoral and cellular immunity in lobomycosis. Allergol Immunopathol (Madr). 1979;7(6):439-444.

29. Vilani-Moreno FR, BeloneAde F, Lara VS, Venturini J, Lauris JR, Soares CT. Detection of cytokines and nitric oxide synthase in skin lesions of Jorge Lobo's disease patients. Med Mycol. 2011;49(6):643-648.
30. Quaresma JA, de Oliveira E, Cardoso de Brito A. Is TGF-beta important for the evolution of subcutaneuos chronic mycoses? Med Hypotheses. 2008;70(6):1182-1185.

31. Xavier MB, Libonati RM, Unger D, et al. Macrophage and TGF-beta immunohistochemical expression in Jorge Lobo's disease. Hum Pathol. 2008;39(2):269-274.

32. Smeltz RB, Chen J, Shevach EM. Transforming growth factor-beta1 enhances the interferon-gamma-dependent, interleukin-12-independent pathway of T helper 1 cell differentiation. Immunology. 2005;114(4): 484-492.

33. Quaresma JA, Lima LW, Fuzii HT, Libonati RM, Pagliari C, Duarte MI. Immunohistochemical evaluation of macrophage activity and its relationship with apoptotic cell death in the polar forms of leprosy. Microb Pathog. 2010;49(4):135-140.

34. Geller P, Geller M. Cytokines and immune regulation. An Acad Nac Med. 1997;157:97-102.

35. Pecher SA, Fuchs J. Cellular immunity in lobomycosis (keloidal blastomycosis). Allergol Immunopathol (Madr). 1988;16(6):413-415.

36. Vilani-Moreno FR, Mozer E, de Sene AM, et al. In vitro and in situ activation of the complement system by the fungus Lacazia loboi. Rev Inst Med Trop Sao Paulo. 2007;49(2):97-101.

37. Quaresma JA, Unger D, Pagliari C, Sotto MN, Duarte MI, de Brito AC. Immunohistochemical study of Langerhans cells in cutaneous lesions of the Jorge Lobo's disease. Acta Trop. 2010;114(1):59-62.

38. Goihman-Yahr M, Cabello de Brito I, Bastardo de Albornoz MC, et al. Functions of polymorphonuclear leukocytes and individuality of Jorge Lobo's disease: absence of the specific leukocyte digestive defect against Paracoccidioides brasiliensis. Mycoses. 1989;32(12):603-608.

39. Vilani-Moreno FR, Silva LM, Opromolla DV. Evaluation of the phagocytic activity of peripheral blood monocytes of patients with Jorge Lobo's disease. Rev Soc Bras Med Trop. 2004;37(2):165-168.

40. Vilani-Moreno FR, Lauris JR, Opromolla DV. Cytokine quantification in the supernatant of mononuclear cell cultures and in blood serum from patients with Jorge Lobo's disease. Mycopathologia. 2004;158(1): 17-24.

41. Taborda VB, Taborda PR, McGinnis MR. Constitutive melanin in the cell wall of the etiologic agent of Lobo's disease. Rev Inst Med Trop Sao Paulo. 1999;41(1):9-12.

42. Vilani-Moreno FR, Opromolla DV. Determinação da viabilidade do Paracoccidioides loboi em biópsias de pacientes portadores de doença de Jorge Lobo. Ann Bras Dermatol (Rio de Janeiro). 1997;72(5):433-437.

43. Stenger S, Mazzaccaro RJ, Uyemura K, et al. Differential effects of cytolytic T cell subsets on intracellular infection. Science. 1997;276(5319):1684-1687.

44. Ochoa MT, Stenger S, Sieling PA, et al. T-cell release of granulysin contributes to host defense in leprosy. Nat Med. 2001;7(2):174-179.

45. Levitz SM, Dupont MP, Smail EH. Direct activity of human T lymphocytes and natural killer cells against Cryptococcus neoformans. Infect Immun. 1994;62(1):194-202.

46. Camargo ZP, Baruzzi RG, Maeda SM, Floriano MC. Antigenic relationship between Loboa loboi and Paracoccidioides brasiliensis as shown by serological methods. Med Mycol. 1998;36(6):413-417.

47. Mendoza L, Belone AF, Vilela R, et al. Use of sera from humans and dolphins with lacaziosis and sera from experimentally infected mice for Western Blot analyses of Lacazia loboi antigens. Clin Vaccine Immunol. 2008;15(1):164-167.

48. Silva D. Estudo experimental da micose de Lobo. An Bras Dermatol. 1994;69:88-91.

49. Azulay RD, Carneiro JA, Da Graça M, Cunha S, Reis LT. Keloidal blastomycosis (Lobo's disease) with lymphatic involvement: a case report. Int J Dermatol. 1976;15(1):40-42.

50. Rosa PS, Soares CT, Belone Ade F, et al. Accidental Jorge Lobo's disease in a worker dealing with Lacazia loboi infected mice: a case report. J Med Case Rep. 2009;3:67.

51. Borelli D. La Reservarea de al Lobomicosis Comentarios a un Trabajo del Dr. Carlos Peña sobre dos casos Colombianos [The reservoir area of lobomycosis. Comments on the work of Dr Carlos Peña on 2 Colombian cases]. Mycopathol Mycol Appl. 1969 28;37(2):145-149. Spanish. 
52. Guimaraes FN, Macedo DG. Contribuição ao estudo das blastomicoses na Amazônia (blastomicose queloidiana e blastomicose sul-americana) [Blastomycosis in the Amazon Valley (keloidian and South American)]. Hospital (Rio J). 1950;38(2):223-253. Portuguese.

53. Moraes MAP, Oliveira WR. Novos casos da micose de Jorge Lobo encontrados em Manaus, Amazonas (Brasil). Rev Inst Med Trop Sao Paulo. 1962;4:403-406.

54. Nazaré IP. Micose de Lobo. Belém: Grafisa; 1976.

55. Migaki G, Valerio MG, Irvine B, Garner FM. Lobo's disease in an atlantic bottle-nosed dolphin. J Am Vet Med Assoc. 1971;159(5):578-582.

56. Bossart GD. Suspected acquired immunodeficiency in an Atlantic bottlenosed dolphin with chronic-active hepatitis and lobomycosis. J Am Vet Med Assoc. 1984;185(11):1413-1414.

57. Rotstein DS, Burdett LG, McLellan W, et al. Lobomycosis in offshore bottlenose dolphins (Tursiops truncatus), North Carolina. Emerg Infect Dis. 2009;15(4):588-590.

58. Paniz-Mondolfi AE, Sander-Hoffmann L. Lobomycosis in inshore and estuarine dolphins. Emerg Infect Dis. 2009;15(4):672-673.

59. Kiszka J, Van Bressem MF, Pusineri C. Lobomycosis-like disease and other skin conditions in Indo-Pacific bottlenose dolphins Tursiops aduncus from the Indian Ocean. Dis Aquat Organ. 2009;84(2):151-157.

60. Caldwell DK, Caldwell MC, Woodard JC, Ajello L, Kaplan W, McClure HM. Lobomycosis as a disease of the Atlantic bottle-nosed dolphin (Tursiops truncatus Montagu, 1821). Am J Trop Med Hyg. 1975;24(1):105-114.

61. Reif JS, Schaefer AM, Bossart GD. Lobomycosis: risk of zoonotic transmission from dolphins to humans. Vector Borne Zoonotic Dis. 2013;13(10):689-693.

62. Daura-Jorge FG, Simões-Lopes PC. Lobomycosis-like disease in wild bottlenose dolphins Tursiops truncatus of Laguna, southern Brazil: monitoring of a progressive case. Dis Aquat Organ. 2011;93(2):163-170.

63. Van Bressem MF, Santos MC, Oshima JE. Skin diseases in Guiana dolphins (Sotalia guianensis) from the Paranaguá estuary, Brazil: a possible indicator of a compromised marine environment. Mar Environ Res. 2009;67(2):63-68.

64. Rodriguez-Toro G. Enfermedad de Jorge Lobo o blastomicosis queloidiana. Nuevos aspectos de la entidad en Colombia. Rev Bioméd (Bogota). 1989;9:133-146.

65. Rodríguez-Toro G, Tellez N. Lobomycosis in Colombian Amer Indian patients. Mycopathologia. 1992;120(1):5-9.

66. Reif JS, Peden-Adams MM, Romano TA, Rice CD, Fair PA, Bossart GD. Immune dysfunction in Atlantic bottlenose dolphins (Tursiops truncatus) with lobomycosis. Med Mycol. 2009;47(2):125-135.

67. Bermudez L, Van Bressem MF, Reyes-Jaimes O, Sayegh AJ, PanizMondolfi AE. Lobomycosis in man and lobomycosis-like disease in bottlenose dolphin, Venezuela. Emerg Infect Dis. 2009;15(8): 1301-1303.

68. Paniz Mondolfi A. Lobomicosis: una aproximación después de 70 años. Dermatol Venez. 2003;41(1):3-7.

69. Paniz-Mondolfi A, Talhari C, Sander Hoffmann L, et al. Lobomycosis: an emerging disease in humans and delphinidae. Mycoses. 2012;55(4):298-309

70. Paniz-Mondolfi AE, Reyes Jaimes O, Dávila Jones L. Lobomycosis in Venezuela. Int J Dermatol. 2007;46(2):180-185.

71. Rosales T, Reyes Jaimes O, et al. Keloidal and verrucous lesions in an Amerindian patient. Clin Exp Dermatol. 2010;35(4):e205-e206.

72. Pradinaud R. Entre le Yucatan, la Floride et la Guyane Française, la lomycose exite-ti-elle aux Antilles? [Between Yucatan, Florida and French Guiana does lobomycosis exist in the Antilles?]. Bull Soc Pathol Exot Filiales. 1984;77(3):392-400. French.

73. Pradinaud R, Grosshans E, Basset M. Un nouveau cas de maladie de Jorge Lobo en Guyane Française. [A new case of Jorge Lobo disease in French Guyana]. Bull Soc Fr Dermatol Syphiligr. 1969;76(6):837-839. French.

74. Pradinaud R, Joly F, Basset M, Basset A, Grosshans E. Les chromomycoses et la maladie de Jorge Lobo en Guyane Française. [Chromomycosis and Jorge Lobo disease in French Guiana]. Bull Soc Pathol Exot Filiales. 1969;62(6):1054-1063. French.
75. Garzón Aldás E, Herrera Vicuña V. Lobomicosis: una serie de 5 casos. Piel. 2013;28(5):260-263.

76. Rivas OR. Enfermedad de Jorge Lobo: primer caso diagnosticado en el Peru. Arch Peruanos Pat Clin. 1972;26:63-86.

77. Talhari S, Cuba Caparo A, Ganter B. Enfermedad de Jorge Lobo. Segundo caso peruano [Jorge Lobo's disease. Second Peruvian case]. Med Cutan Ibero Lat Am. 1985;13(3):201-204. Spanish.

78. Bustamante B, Seas C, Salomon M, Bravo F. Lobomycosis successfully treated with posaconazole. Am J Trop Med Hyg. 2013;88(6): $1207-1208$

79. Recacoechea M, Vargas J. Experiencia con el ketoconazole en el primer caso de lobomicosis en Bolivia. Bol Inf CENETROP. 1982;8:23-26.

80. Herrera JM. Paracoccidioides brasiliense: estudio del primer caso observado en Panama de blastomicosis sudamericana en su forma cutanea queloideana o enfermedad de Lobo, y propuesta de una variante tecnica para la impregnacion argentica del parasito. Arch Med Panameños. 1955;4:209-2019.

81. Tapia A, Torres-Calcindo A, Arosemena R. Keloidal blastomycosis (Lobo's disease) in Panama. Int J Dermatol. 1978;17(7):572-574

82. Fonseca JJ. Lobomycosis. Int J Surg Pathol. 2007;15(1):62-63.

83. Burns RA, Roy JS, Woods C, Padhye AA, Warnock DW. Report of the first human case of lobomycosis in the United States. J Clin Microbiol. 2000;38(3):1283-1285.

84. Elsayed S, Kuhn SM, Barber D, Church DL, Adams S, Kasper R. Human case of lobomycosis. Emerg Infect Dis. 2004;10(4):715-718.

85. Saint-Blancard P, Maccari F, Le Guyadec T, Lanternier G, Le Vagueresse R. La lobomycose: une mycose rarement observée en France métropilitaine. [Lobomycosis: a mycosis seldom observed in metropolitan France]. Ann Pathol. 2000;20(3):241-244. French.

86. Symmers WS. A possible case of Lôbo's disease acquired in Europe from a bottle-nosed dolphin (Tursiops truncatus). Bull Soc Pathol Exot Filiales. 1983;76(5 Pt 2):777-784.

87. Fischer M, Chrusciak Talhari A, Reinel D, Talhari S. Lobomykose Erfolgreiche Therapie mit Clofazimin und Itrakonazol bei einem 46jährigen Patienten nach 32-jähriger Krankheitsdauer. [Sucessful treatment with clofazimine and itraconazole in a 46 year old patient after 32 years duration of disease]. Hautarzt. 2002;53(10):677-681. German.

88. Papadavid E, Dalamaga M, Kapniari I, et al. Lobomycosis: A case from Southeastern Europe and review of the literature. J Dermatol Case Rep. 2012;6(3):65-69.

89. Baruzzi RG, Castro RM, D’Andretta C Jr, Carvalhal S, Ramos OL, Pontes PL. Occurrence of Lobo's blastomycosis among "Caiabi," Brazilian Indians. Int J Dermatol. 1973;12(2):95-99.

90. Machado PA, Silveira DF. Piraip, a falsa lepra dos Caiabis. Rev Bras Leprol. 1966;34:60.

91. Baruzzi RG, Marcopito LF, Vicente LS, Michalany NS. Jorge Lobo's disease (keloidal blastomycosis) and tinea imbricata in Indians from the Xingu National Park, Central Brazil. Trop Doct. 1982;12(1):13-15.

92. Baruzzi RG, Marcopito LF. Doença de Jorge Lobo. In: Veronesi R, Focaccia R, editors. Tratado de Infectologia. São Paulo: Atheneu; 1996:1116-1119.

93. Baruzzi RG, d'Andretta C Jr, Carvalhal S, Ramos OL, Pontes PL. Ocorrência de blastomicose queloideana entre índios Caiabí. [Occurrence of keloidal blastomycosis among Caiabi Indians]. Rev Inst Med Trop Sao Paulo. 1967;9(3):135-142. Portuguese.

94. Baruzzi RG, Lacaz Cda S, de Souza FA. História natural da doença de Jorge Lobo. Ocorrência entre os índios Caiabí (Brasil Central). [Natural history of Jorge Lobo's disease. Occurrence among the Caiabi Indians (Central Brazil)]. Rev Inst Med Trop Sao Paulo. 1979;21(6):303-338. Portuguese.

95. Baruzzi RG, Marcopito LF, Michalany NS, Livianu J, Pinto NR. Early diagnosis and prompt treatment by surgery in Jorge Lobo's disease (keloidal blastomycosis). Mycopathologia. 1981;74(1):51-54.

96. Machado PA. Regressão espontânea de lesões maculosas na blastomicose de Jorge Lobo. Acta Amaz. 1972;2:47-50.

97. Rodríguez G. Nuevos casos colombianos de lobomicosis. Biomedica. 1994;14(4):239-241. 
98. Wiersema JP, Niemel PL. Lobo's disease in Surinam patients. Trop Geogr Med. 1965;17(2):89-111.

99. De Vries GA, Laarman JJ. A case of Lobo's disease in the dolphin Sotalia guianensis. Aquat Mamm. 1973;1:26-33.

100. Al-Daraji WI, Husain E, Robson A. Lobomycosis in African patients. Br J Dermatol. 2008;159(1):234-236.

101. Norton SA. Dolphin-to-human transmission of lobomycosis? J Am Acad Dermatol. 2006;55(4):723-724.

102. Haubold EM, Cooper CR Jr, Wen JW, McGinnis MR, Cowan DF. Comparative morphology of Lacazia loboi (syn. Loboa loboi) in dolphins and humans. Med Mycol. 2000;38(1):9-14.

103. Esperón F, García-Párraga D, Bellière EN, Sánchez-Vizcaíno JM. Molecular diagnosis of lobomycosis-like disease in a bottlenose dolphin in captivity. Med Mycol. 2012;50(1):106-109.

104. Woods WJ, Belone Ade F, Carneiro LB, Rosa PS. Ten years experience with Jorge Lobo's disease in the state of Acre, Amazon region, Brazil. Rev Inst Med Trop Sao Paulo. 2010;52(5):273-278.

105. Vilela R, Mendoza L, Rosa PS, et al. Molecular model for studying the uncultivated fungal pathogen Lacazia loboi. J Clin Microbiol. 2005;43(8):3657-3661.

106. Azulay RD, Carneiro Jde A, de Andrade LC. Micose de Jorge Lobo. Contribuição ao seu estudo experimental. Inoculações no homem e animais de laboratório e investigação imunológica. [Jorge Lobo blastomycosis. Etiology, experimental inoculation, immunology and pathology of the disease]. An Bras Dermatol. 1970;45(1):47-66. Portuguese.

107. Opromolla DV, Belone AF, Taborda PR, Rosa PS. Lymph node involvement in Jorge Lobo's disease: report of two cases. Int J Dermatol. 2003;42(12):938-941.

108. Nogueira L, Mendes L, Rodrigues CA, Santos M, Talhari S, Talhari C. Lobomycosis and squamous cell carcinoma. An Bras Dermatol. 2013;88(2):293-295.

109. Silva D. Micose de Lobo. Rev Soc Bras Med Trop. 1972;6:85-98.

110. Silva D, Brito A. Formas clínicas não usuais da micose de Lobo. An Bras Dermatol. 1994;69:133-136.

111. Machado PA. Polimorfismo das lesões dermatológicas na blastomicose de Jorge Lobo entre os índios Caiabi. Acta Amaz. 1972;2:93-97.

112. Miranda MF, Silva AJ. Vinyl adhesive tape also effective for direct microscopy diagnosis of chromomycosis, lobomycosis, and paracoccidioidomycosis. Diagn Microbiol Infect Dis. 2005;52(1):39-43.

113. Miranda MF, Costa VS, Bittencourt Mde J, Brito AC. Eliminação transepidérmica de parasitas na doença de Jorge Lobo [Transepidermal elimination of parasites in Jorge Lobo's disease]. An Bras Dermatol. 2010;85(1):39-43. Portuguese.
114. Talhari C, Chrusciak-Talhari A, de Souza JV, Araújo JR, Talhari S. Exfoliative cytology as a rapid diagnostic tool for lobomycosis. Mycoses. 2009;52(2):187-189.

115. Ramos-E-Silva M, Aguiar-Santos-Vilela F, Cardoso-de-Brito A, Coelho-Carneiro S. Lobomycosis. Literature review and future perspectives. Actas Dermosifiliogr. 2009;100 Suppl 1:92-100.

116. de Andrade LM, Azulay RD, Carneiro J. Micose de Jorge Lobo.(Estudo histopatológico). [Jorge Lobo mycosis(histopathological study)]. Hospital (Rio J). 1968;73(4):1173-1184. Portuguese.

117. Vilani-Moreno FR, Belone AF, Soares CT, Opromolla DV. Immunohistochemical characterization of the cellular infiltrate in Jorge Lobo's disease. Rev Iberoam Micol. 2005;22(1):44-49.

118. Dudok van Heel WH. Successful treatment in a case of lobomycosis (Lobo's Disease) in Tursiops truncatus (Mont) at Dolfinarium, Harderwijk. Aquat Mamm. 1977;5:8-15.

119. Lawrence DN, Ajello L. Lobomycosis in western Brazil: report of a clinical trial with ketoconazole. Am J Trop Med Hyg. 1986;35(1): $162-166$.

120. Cucé LC, Wroclawski EL, Sampaio SA. Treatment of paracoccidioidomycosis, candidiasis, chromomycosis, lobomycosis, and mycetoma with ketoconazole. Int J Dermatol. 1980;19(7): 405-408.

121. Londoño F. Blastomicosis queloidiana. A propósito de un caso tratado con anfotericina B. Med Cutan Ibero Lat Am. 1968;2:521-524.

122. Reyes O, Goihman M, Goldstein C. Blastomicosis queloidiana o enfermedad de Jorge Lobo. Comunicación previa sobre un caso observado. Derm Venez. 1960;2:245-255.

123. Silverie R, Ravisse P, Vilar JP, Moulins C. Blastomycosis chéloidienne ou maladie du Jorge Lobo en Guyane française. [Keloid blastomycosis or Jorge Lobo disease in French Guiana]. Bull Soc Pathol Exot Filiales. 1963;56:29-35. French.

124. Carneiro FP, Maia LB, Moraes MA, et al. Lobomycosis: diagnosis and management of relapsed and multifocal lesions. Diagn Microbiol Infect Dis. 2009;65(1):62-64.

125. Baruzzi RG, Azevedo RA. Doença de Jorge Lobo. In: Meira DA. Clínica de doenças tropicais e infecciosas. Rio de Janeiro: Interlivros; 1991:299-306.

126. Silva D. Traitement de la maladie de Jorge Lobo par la clofazimine (B663). [Treatment of Lobo's disease with clofazimine (B 663)]. Bull Soc Pathol Exot Filiales. 1978;71(6):409-412. French.

127. Talhari S, Cunha MG, Barros ML, Gadelha AD. Enfermedad de Jorge Lobo: Estudio de 22 casos. [Jorge Lobo disease. Study of 22 new cases]. Med Cutan Ibero Lat Am. 1981;9(2):87-96. Spanish.
Therapeutics and Clinical Risk Management

\section{Publish your work in this journal}

Therapeutics and Clinical Risk Management is an international, peerreviewed journal of clinical therapeutics and risk management, focusing on concise rapid reporting of clinical studies in all therapeutic areas, outcomes, safety, and programs for the effective, safe, and sustained use of medicines. This journal is indexed on PubMed Central, CAS,
Dovepress

EMBase, Scopus and the Elsevier Bibliographic databases. The manuscript management system is completely online and includes a very quick and fair peer-review system, which is all easy to use. Visit http://www.dovepress.com/testimonials.php to read real quotes from published authors. 